\section{Arqueologia do edificado em contexto de Arqueologia preventiva: o exemplo da Baixinha de Coimbra (Portugal)}

\section{Building Archaeology in rescue archaeology context: the example of Baixinha de Coimbra (Portugal)}

Lília Basílio*

Miguel Almeida

(Dryas Octopetala / iDryas)

\section{Resumo}

Em Portugal a inclusão de estudos detalhados dos edifícios a demolir no contexto de intervenções de Arqueologia preventiva / de salvamento permanece rara, reservando-se a leitura e interpretação dos conjuntos edificados quase exclusivamente para projectos específicos da área da Conservação e restauro, maioritariamente de edifícios com carácter monumental. Esta situação tem provocado perdas irrecuperáveis de informação fundamental para a história das cidades portuguesas. Uma intervenção de Arqueologia preventiva, prévia à execução de um projecto de construção com impacto significativo sobre a malha urbana actual da Baixinha de Coimbra, constituiu uma oportunidade singular para o desenvolvimento de um projecto global de Arqueologia que articula a análise do edificado com trabalhos de escavação arqueológica. O projecto da Baixinha de Coimbra (actualmente em curso, mesmo no que respeita aos trabalhos de aquisição de dados no terreno) demonstra: (1) a relevância e o potencial informativo dos edifícios de arquitectura civil, quando encarados como objectos estratificados cuja compreensão surge indispensável para a reconstituição da história dos centros urbanos; e (2) o papel fundamental a desempenhar pela Arqueologia preventiva neste processo fundamental de construção de conhecimento sobre a história das cidades.

Neste sentido, insistimos sobre a necessidade urgente de constituicão de colecções de referência de materiais e técnicas construtivas geográfica e cronologicamente contextualizadas e da imposição do princípio de "conhecer para intervir», elevando o conhecimento objectivo da história dos edifícios e da sua envolvente urbana à categoria de eixo fundamental das opções estratégicas dos programas de intervenção urbana, maxime no caso de centros históricos.

Palavras-chave: Arqueologia Preventiva, Arqueologia do edificado, Arquitectura Civil

\section{Abstract}

It is not common in Portugal, within the rescue archaeology context, the inclusion of detailed recordings of buildings to be demolished. Recording and interpretation of standing buildings are almost limited to restoration and preservation projects, mainly affecting monumental buildings. It is therefore that fundamental information for the history of Portuguese cities is being lost.

Previously to a building project with huge impact on the current urban city wall of Baixinha de Coimbra, a rescue archaeological work to be carried out in the mentioned area was the singular chance to develop a global archaeological project including both standing building and ground archaeology.

The project of Baixinha de Coimbra (currently running, although lands to build on have been not yet acquired) shows: firstly, the relevance and informative potential of civil architecture when considered as stratified object whose understanding is essential to build up the history of urban centres; secondly, the fundamental role to be played by the rescue archaeology within that process of knowing the history of the cities. In that sense, this paper insists on the urgent need of having corpora of materials and building techniques geographically and chronologically contextualised, and on the requirement of «knowing to intervene», converting thus the knowledge of the history of the buildings and its urban development into the main axis of strategic options of the urban developing projects, mainly in historic centres.

Keywords: Rescue Archaeology, Building Archaeology, Civil Architecture.

\footnotetext{
*lilia.basilio@dryas.pt; miguel.almeida@dryas.pt
}

\section{CONTEXTO DO PROJECTO}

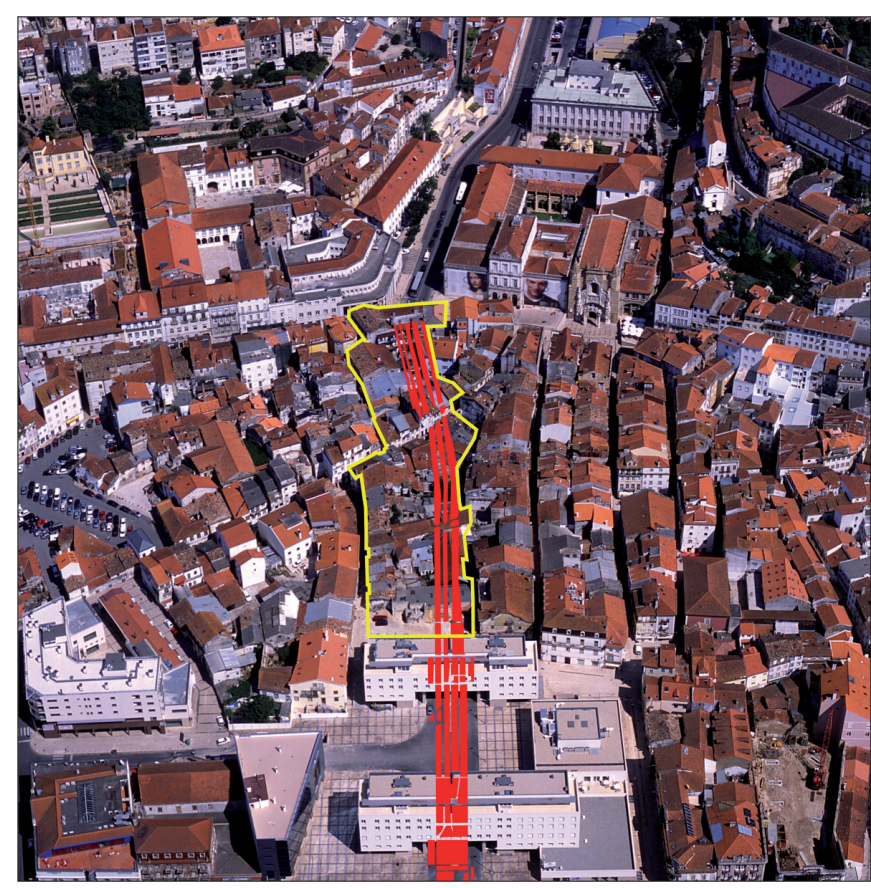

Fig. 1. Vista geral da Baixinha de Coimbra, com inserção do novo canal viário sobre malha urbana antiga. A amarelo a área de construção antiga a afectar pelo projecto (imagem fornecida pela Metro Mondego, S.A.)

$\mathrm{Na}$ prática arqueológica portuguesa actual, os estudos de Arqueologia do edificado constituem ainda uma vertente significativamente negligenciada (Ramalho, 2004), sobretudo quando considerado o enorme potencial informativo deste tipo de trabalhos para a compreensão da história do urbanismo das nossas cidades. Com efeito, apesar da realização de alguns trabalhos sobre edifícios de carácter «monumental», o estudo detalhado dos conjuntos edificados é particularmente raro no quadro de intervenções de Arqueologia preventiva. Porém, parte significativa das intervençōes desta Arqueologia preventiva tem ocorrido em consequência de projectos de construção localizados em áreas urbanas de grande profundidade histórica.

Nestes termos, a oportunidade de proceder ao estudo consequente de muitos edifícios históricos tem sido assim desperdiçada por insuficiente compreensão do potencial informativo do objecto construído como fonte histórica. Resulta uma insuprível deficiência metodológica das abordagens de estudo desses edifícios, com grave perda de informação para a história do urbanismo, em linha com a sistemática insuficiência de investimento em programas estruturados de investigação transdisciplinar capazes de combinar a análise do edificado, enquanto objecto estratificado, com o estudo do registo arqueológico preservado a cota negativa. 
Contrariamente a esta tendência generalizada, o trabalho de Arqueologia do edificado actualmente em curso na Baixinha de Coimbra surge exactamente no contexto de uma intervenção de Arqueologia preventiva numa área urbana de grande profundidade histórica e reconhecido potencial arqueológico, a ponto de merecer protecção por classificação patrimonial. O empreendimento que motiva esta intervenção visa a construção de um eixo viário, incluída a instalação de um metro ligeiro de superfície, para além de um conjunto de outras acçōes de construção e arranjo de espaços públicos. A execução deste projecto implicará o desaparecimento de um conjunto de edifícios historicamente muito relevante, numa área urbana de génese antiga (figura 1), a substituir por um contexto urbano totalmente renovado.

Face à escassez de situações comparáveis na Arqueologia portuguesa, e mesmo europeia, a apresentação deste projecto, ainda em curso, visa discutir: (1) a relevância e o potencial informativo dos edifícios de arquitectura civil, quando encarados como objectos estratificados, cuja compreensão surge indispensável para a reconstituição da história urbana dos centros antigos; e (2) o papel fundamental a desempenhar pela Arqueologia preventiva neste processo fundamental de construção de conhecimento sobre a evolução histórica das cidades.

A consciência deste potencial implicará, inexoravelmente, uma evolução da Arqueologia preventiva e de salvamento, a qual deverá desempenhar um papel privilegiado no desenvolvimento futuro da disciplina da Arqueologia do edificado, através de equipas de trabalho transdisciplinares, capazes de produzir conhecimento relevante para a história das cidades portuguesas e, em particular, para a caracterização da sua arquitectura civil.

\section{ESPAÇO URBANO E EDIFÍCIOS EM ESTUDO}

A Baixinha (figura 2) localiza-se entre o Rio Mondego e a colina onde se implantou a acrópole romana (Alarcão, 2008), constituindo uma das primeiras áreas de expansão urbana extra-muros da cidade medieval, desde (pelo menos) o século XII (Alarcão, 2008; Mantas, 1992; Rossa, 2001). Aqui se instala o arrabalde comercial da cidade medieval (Alarcão, 2008; Rossa, 2001), que integrará uma das suas ultimas judiarias (Alarcão, 2008; Loureiro, 1954; Rossa, 2001) e, mais tarde, um conjunto significativo de pequenas unidades de produção de faiança, indústria relevante na história da cidade entre os séculos XVI e XIX

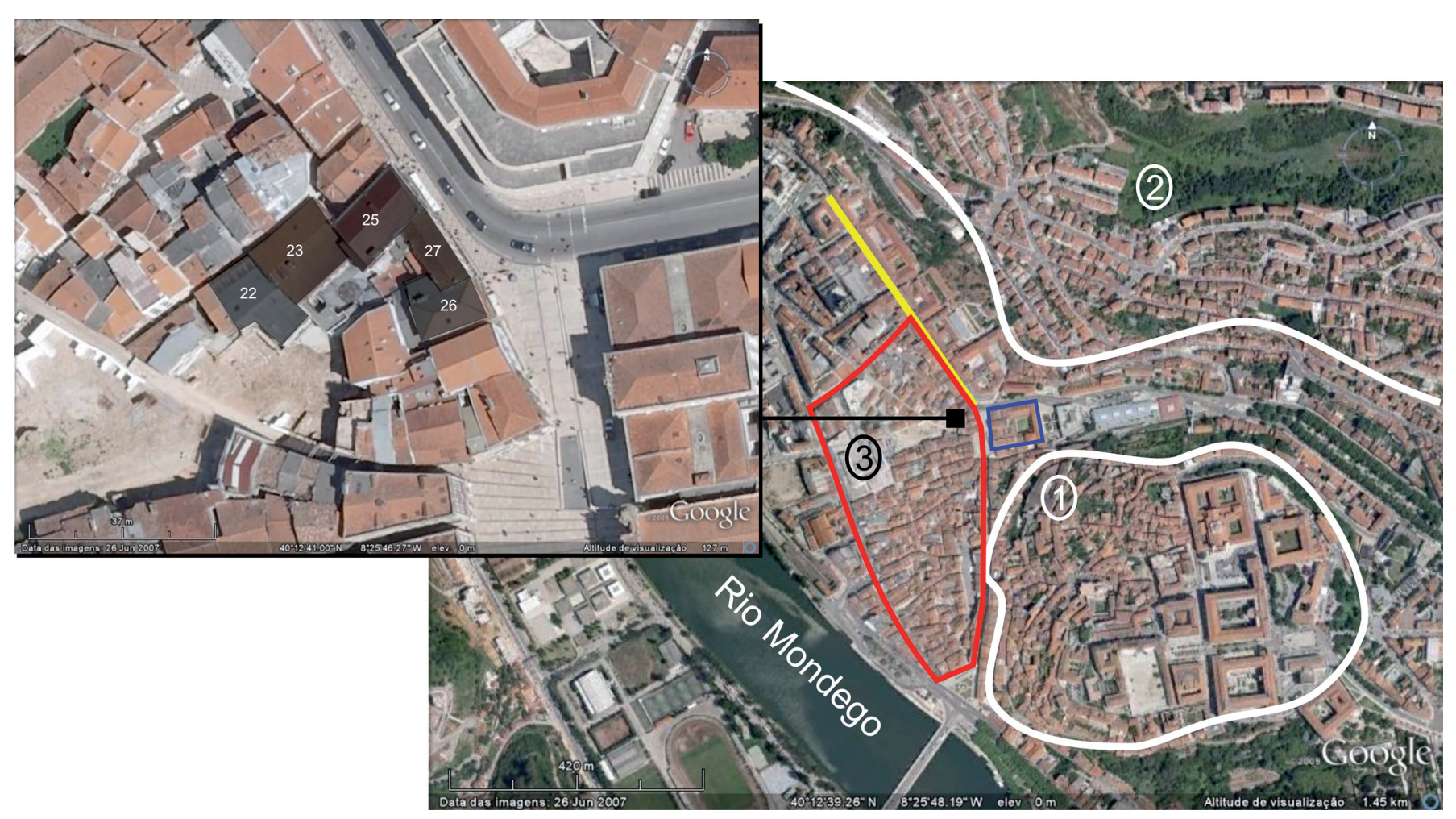

Fig. 2. Pormenor da malha urbana de Coimbra: a vermelho os limites da Baixinha; a amarelo a Rua da Sofia; a azul o Mosteiro de Santa Cruz; (1) a zona da «alta», onde se implantou a acrópole romana; (2) Montearroio; (3) área de implantação das olarias na Baixinha. Em destaque a área de implantação dos cinco edifícios em estudo, no limite entre a Baixinha e a Rua da Sofia (fonte da imagem de base: Google Earth) 


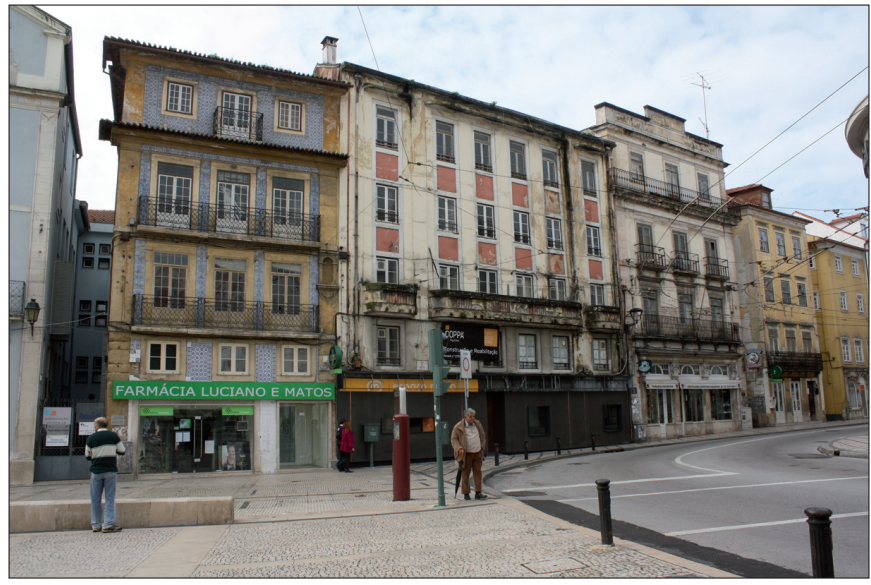

Fig. 3. Fachadas, de estilos arquitectónicos bastante distintos, de três dos cinco edifícios em estudo

(Neves et al., 2006; Pais et al., 2007). A Baixinha - em particular a zona de contacto entre o seu limite Este e as colinas de Montarroio e da cidade intra-muros -, será ainda palco privilegiado da influência estruturante do Mosteiro de Santa Cruz, que aqui se implanta no século XII e que constituirá, ao longo de toda a história medieval e moderna da cidade, uma presença incontornável, com um papel preponderante na sua vida económica, social e cultural (Rossa, 2001; Lobo, 2006).

Apesar da ocupação continuada até aos nossos dias, a Baixinha preserva ainda bastante do seu carácter de arrabalde medieval (Trindade, 2002), evidente nas ruas labirínticas e estreitas, que confluem em pequenos largos dominados por igrejas e capelas, assim como nas suas casas de poucos pisos e fachadas exíguas, que se desenvolvem em profundidade, formando frentes de rua compactas e quarteirões em torno de logradouros interiores. Para além da

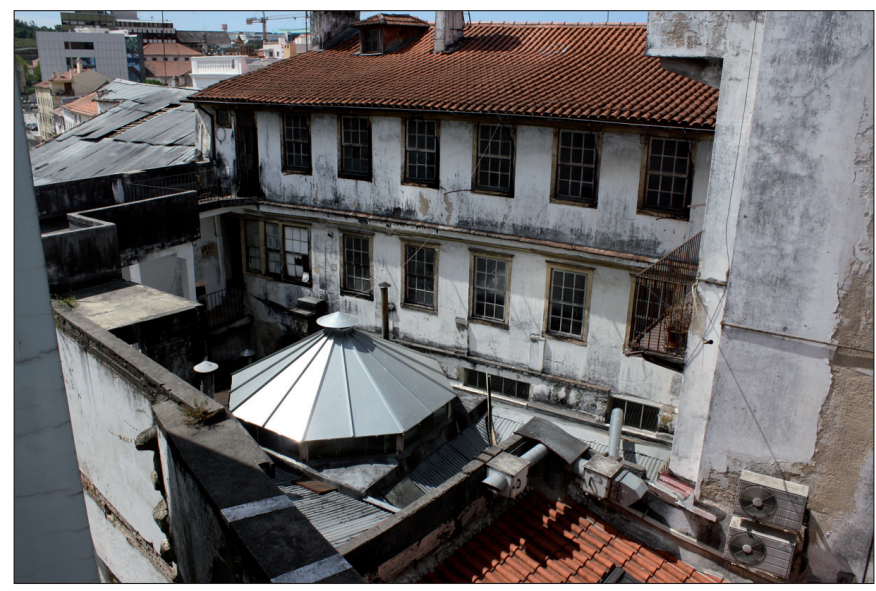

Fig. 4. Aspecto de parte do logradouro definido pelas fachadas traseiras dos edifícios em estudo, actualmente ocupado por uma grande profusão de construções, claramente mais recentes e não programadas morfologia e desenho, pode dizer-se que também se verifica a manutenção do tipo de ocupação deste espaço, eminentemente comercial e de habitação, ainda que - em resultado de dinâmicas urbanas e sociais distintas - algo marginal.

Delimitando este conjunto urbano mais antigo, desenvolvem-se artérias amplas de morfologia regular, maioritariamente resultado de intervençôes urbanísticas dos séculos XIX e XX, com excepção da Rua da Sofia projectada e executada no século XVI para albergar a Universidade que regressava então à cidade de Coimbra (Rossa, 2001; Lobo, 2006).

Neste enquadramento geral, o espaço especificamente interessado pela nossa intervenção é actualmente ocupado por cinco edifícios, localizados no limite NE da Baixinha, onde esta encontra o traçado rectilíneo da Rua da Sofia. Trata-se de edifícios de arquitectura civil, que definem parte de um quarteirão urbano compacto, e cuja observação superficial denunciava desde logo uma história complexas, dadas: (1) a diversidade de características arquitectónicas dos edifícios (figura 3), e (2) a forma não programada como ocuparam progressivamente o antigo espaço de logradouro (figura 4), e os percursos de circulação directa que estabeleceram entre si ao longo do tempo.

\section{OBJECTIVOS, ESTRATÉGIA E METODOLOGIA DA INTERVENÇÃO}

Considerando o impacto significativo do projecto de construção previsto - que resultará na demolição quase integral destes edifícios, com uma afectação também considerável abaixo do solo - definiu-se uma intervenção global de Arqueologia preventiva cujo objectivo principal é a caracterização histórica e patrimonial da área, através do registo exaustivo da realidade actual existente, que se prevê transformar integralmente.

A intervenção será faseada, integrando trabalhos de registo, caracterização e análise dos edifícios existentes e trabalhos de sondagem arqueológica do solo, a executar pela mesma equipa técnica. Com esta estratégia pretendese produzir leituras integradas entre a "cota positiva» e a "cota negativa», que permitam: reconstituir as histórias de construção, reformulação e uso dos edifícios existentes; que contribuam para a compreensão da forma e da história de evolução urbana deste espaço e, em última instância, da cidade de Coimbra.

$\mathrm{Na}$ fase de trabalhos de registo e caracterização do edificado existente a "cota positiva» a intervenção inclui a análise das características arquitectónicas e construtivas (materiais, técnicas e soluçôes) dos edifícios, assim como 

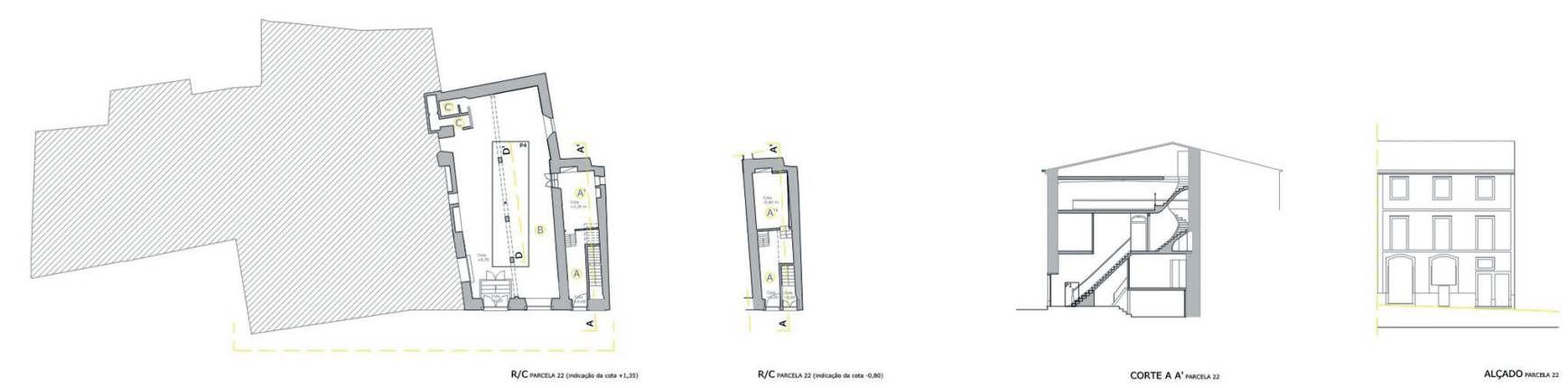

CORTEA':mana

$\mathrm{P} 2$

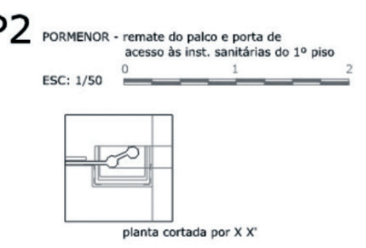

E
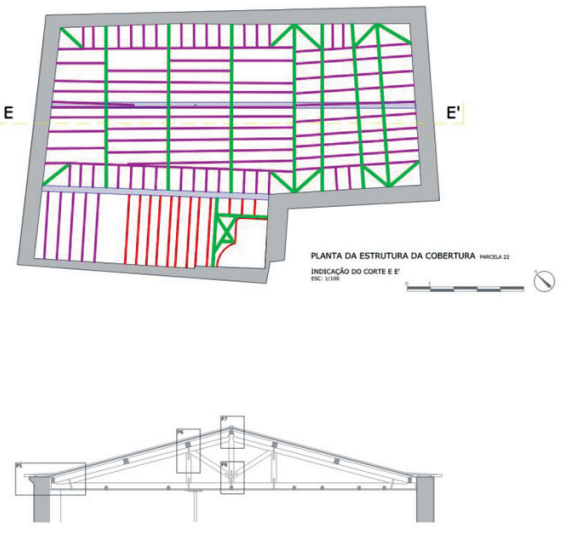

canter - . - w

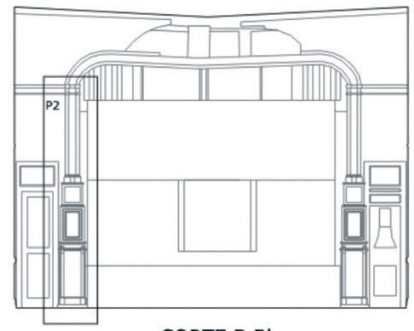

CORTE B B' PARCELA 22

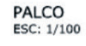
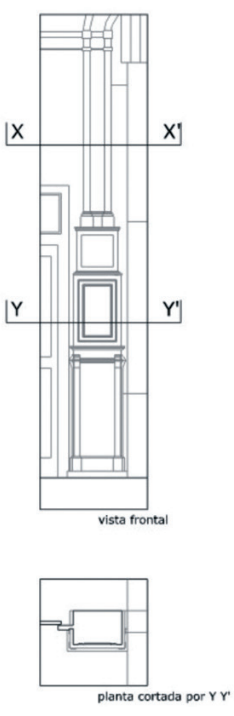
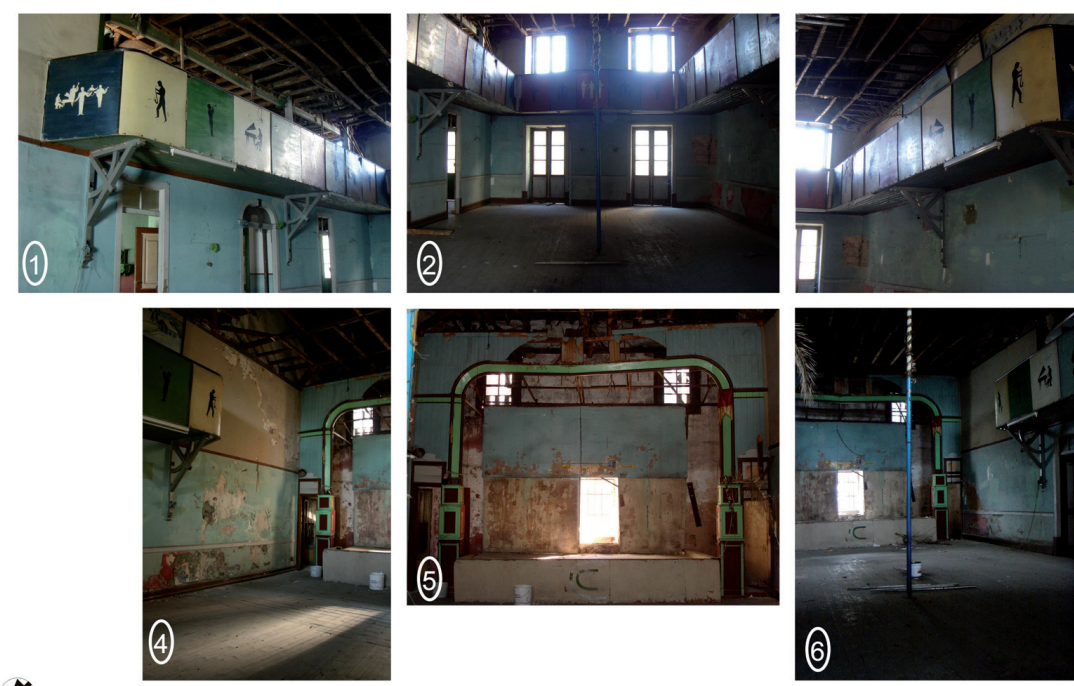


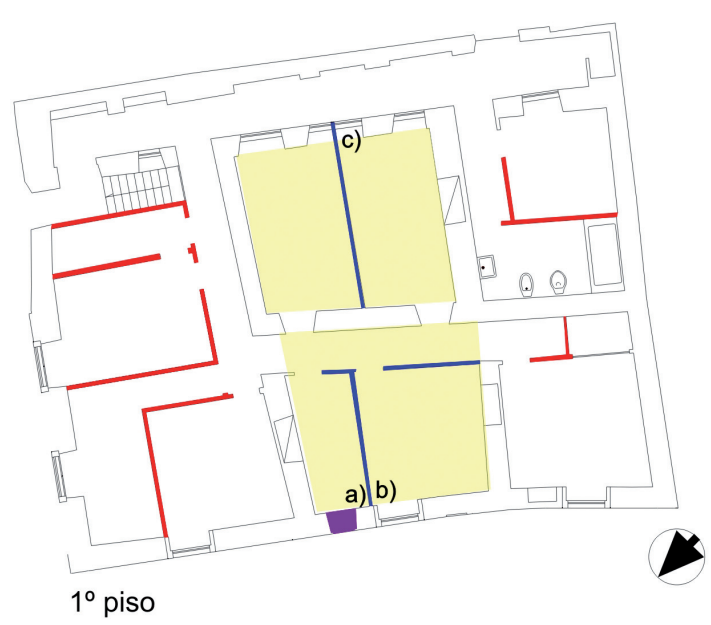

divisões originais

elementos construídos que subdividem espaços amplos originais

elementos construídos que subdividem espaços amplos originais?

vão aberto após compartimentação?
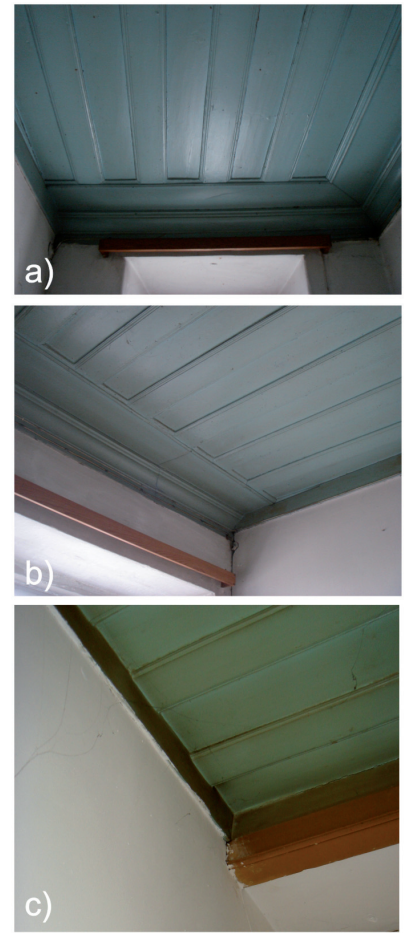

Fig. 6. Exemplo de proposta de transformações de espaço interior elaborado com base na observação das características dos acabamentos do edifício actual, neste caso pelo estabelecimento das relações estratigráficas de sobreposição de algumas parede interiores relativamente ao forro dos tectos, cuja continuidade desenhava divisões mais amplas que as actuais das relações estratigráficas entre elementos construídos, com vista à reconstituição da sua história de formação.

Para tal, os edifícios foram inicialmente analisados na forma em que chegaram à actualidade, procedendo-se ao levantamento arquitectónico do existente, acompanhado de descrição detalhada, sobre ficha de registo, e de registo fotográfico exaustivo (figura 5). Durante estes trabalhos foi possível construir uma ideia bastante precisa das características dos edifícios actuais, incluindo um conjunto de reformulaçōes da organização dos espaços internos (figura 6) e de particularidades arquitectónicas cuja caracterização mais detalhada interessava realizar (figura 7). Procedeu-se neste momento à definição de uma primeira proposta de integração cronológica para cada edifício, exclusivamente com base nas suas características arquitectónicas gerais e em alguns elementos decorativos que integravam.

Foi com base nesta caracterização preliminar que se definiram também as áreas de sondagem parietal a executar, com vista à recolha de informação que permitisse confirmar ou infirmar as primeiras propostas interpretativas destes espaços, assim como recuperar informaçōes essenciais para a compreensão da estratificação geral dos edifícios e das suas características construtivas, nomeadamente de determinados elementos arquitectónicos e organizações de espaço e circulação mais complexas que se registaram (cf, figura 6): as áreas de sondagem foram localizadas em pontos de contacto entre elementos cons-

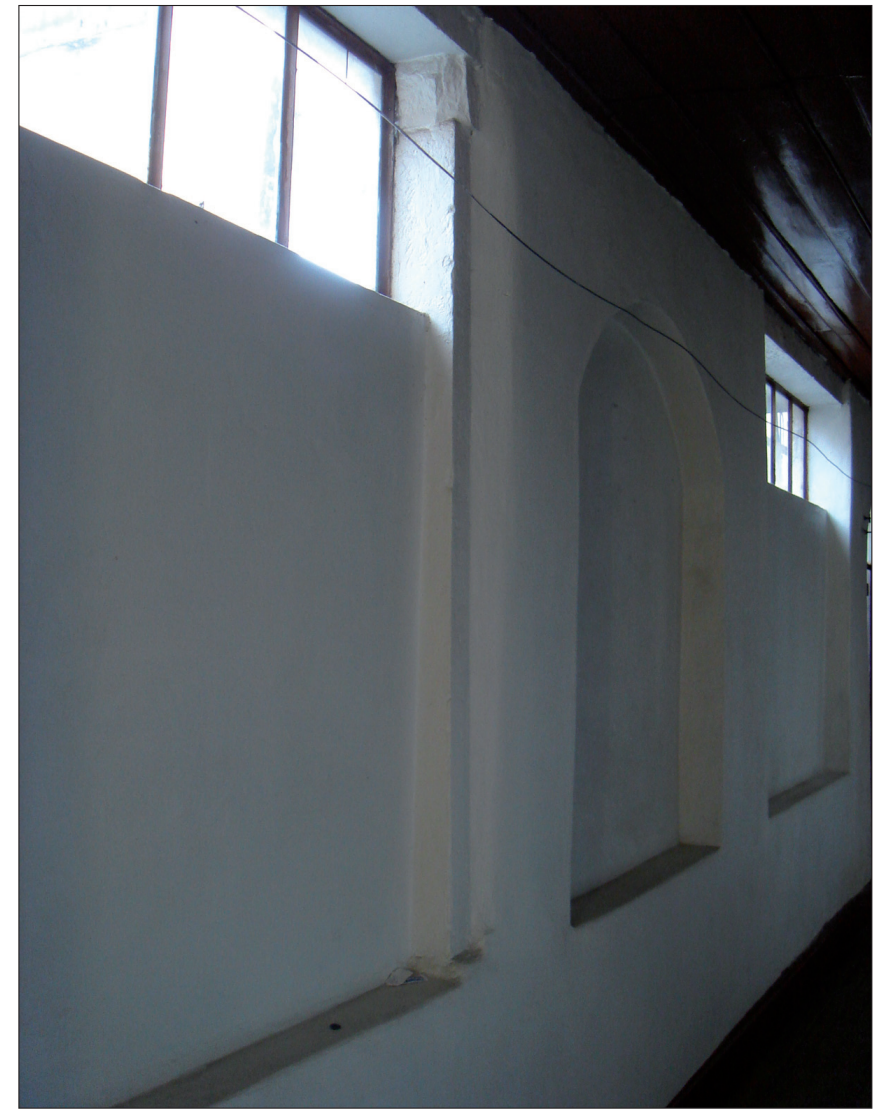

Fig. 7. Parede limite de um corredor, em momento anterior aos trabalhos de sondagem: são evidentes as cantarias e a sobreposição de vários elementos construídos, sugerindo a possibilidade de uma história construtiva complexa, que se pretendeu avaliar em fase de trabalhos de sondagem parietal 


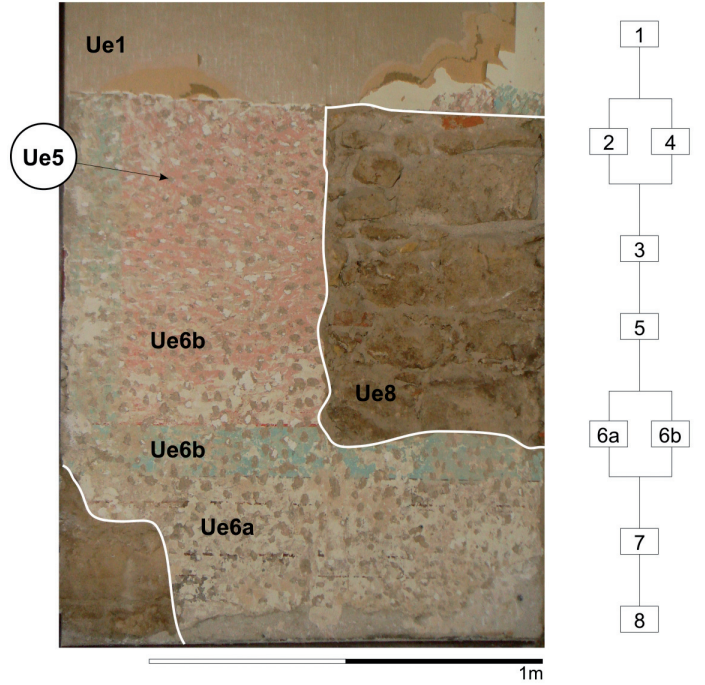

Fig. 8. Sondagem parietal e respectivo diagrama estratigráfico, onde se pode observar diferentes camadas de revestimento, a par de acções de anulação (UE5) dos mais antigos (UE6a, $6 \mathrm{~b}$ e 7), registadas e removidas por ordem inversa à da sua aplicação

truídos cuja relação estratigráfica directa interessava conhecer, assim como sobre elementos arquitectónicos cujas características indiciavam situações de maior complexidade construtiva (cf. figura 7), tentando-se ainda obter informa- ções - sobre materiais e técnicas de construção - relativamente à totalidade dos paramentos que compunham cada um dos edifícios.

Este programa de sondagens consistiu na remoção estratigraficamente controlada das diferentes camadas de revestimento identificadas (figura 8), essencialmente tintas e rebocos. Durante este trabalho procedeu-se à caracterização e registo da sequência estratigráfica dos revestimentos removidos, seguida do registo da estratificação, por vezes complexa, dos elementos construídos, alguns dos quais entretanto revelados pelas sondagens (figura 9).

Para além da sequência estratigráfica identificada, foram documentadas e descritas as técnicas e os materiais de construção utilizados, procedendo-se ainda à recolha sistemática de amostras contextualizadas de materiais de construção (figura 10), nomeadamente de argamassas, rebocos, tintas, madeiras e pregarias.

A totalidade das observações realizadas em cada área de sondagem - materiais, técnicas, alteraçôes arquitectónicas e construtivas, relações e sequências estratigráficas entre elementos - foi compilada em listagens de unidades estratigráficas, e depois organizada e projectada sobre as plantas, cortes e alçados dos edifícios. Este trabalho de
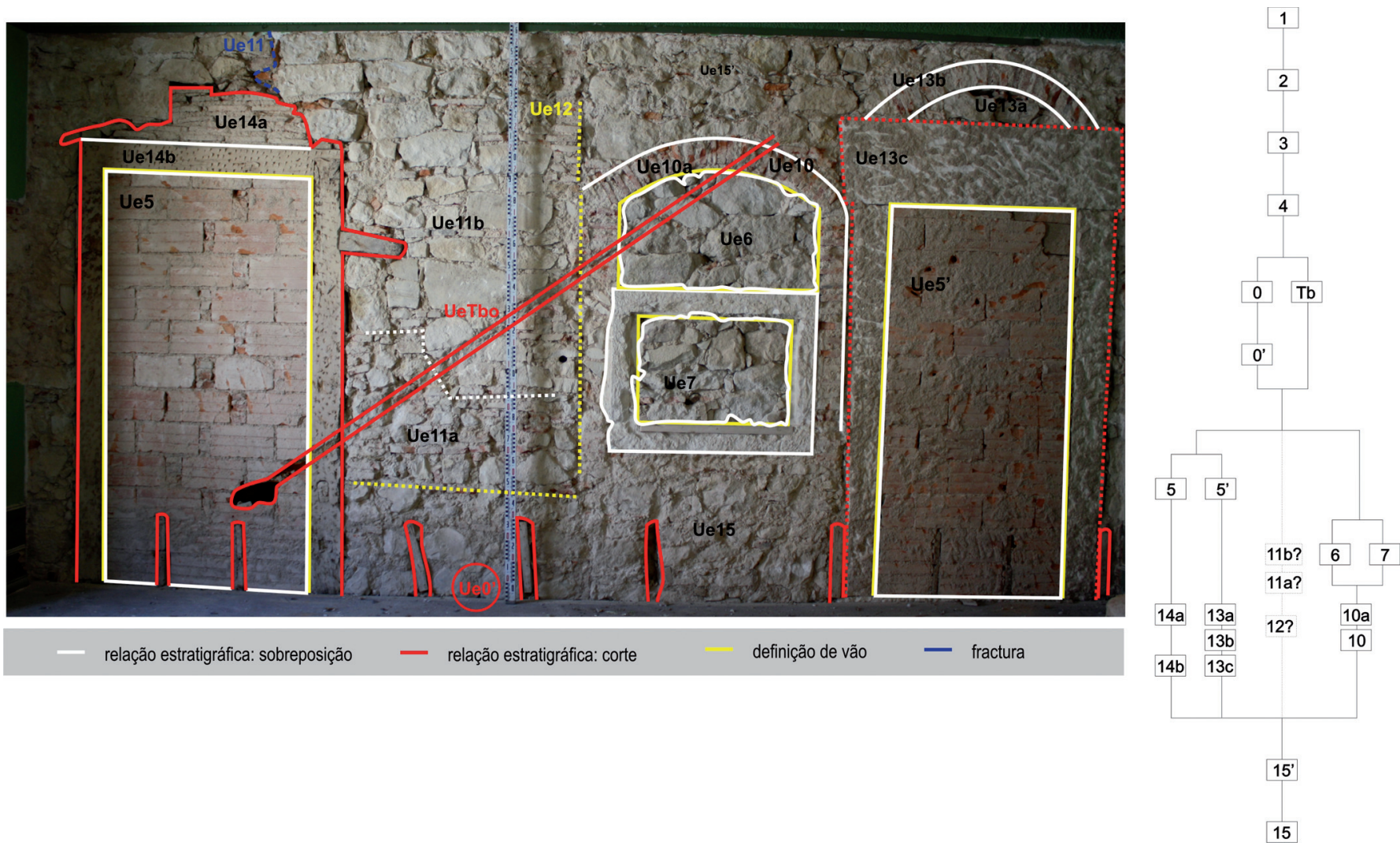

Fig. 9. Exemplo de uma estratificação complexa identificada numa parede interior após remoção de revestimentos: embora actualmente corresponda a uma parede simples que separa duas divisões sem ligação directa, incorporou anteriormente um armário de parede (UE10) e dois vãos de porta (UE13 e UE14) que permitiam a circulação entre as duas divisões, para além de um conjunto de descontinuidades estratigráficas de leitura mais truncada (UE11 e UE12) 


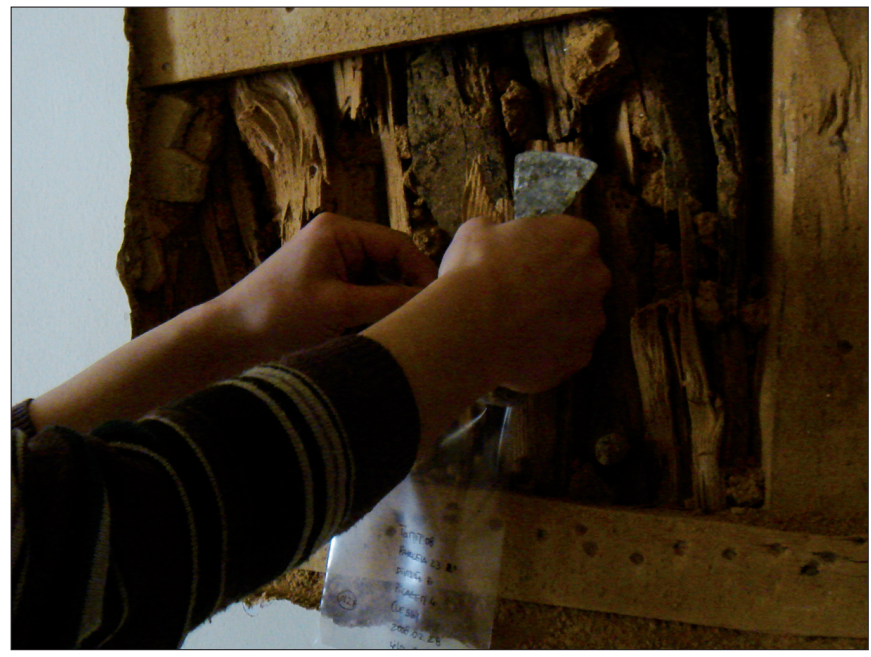

Fig. 10. Recolha de amostras de materiais de construção

cartografia e reconstituição dos ritmos e formas de construção dos edifícios (figura 11), permitiu caracterizar e contextualizar a utilização dos diferentes materiais, técnicas e soluçōes arquitectónicas e construtivas registadas e constituiu a base empírica das propostas de faseamento de cada edifício estudado.

Para além deste trabalho, recorreu-se à análise das fontes cartográficas e iconográficas disponíveis que - pese embora escassas e de modesta resolução para períodos mais antigos - se revelaram complementos cruciais da caracterização estilística dos elementos arquitectónicos e da atribuição cronológica de alguns acabamentos e técnicas de construção mais recentes para a definição de balizas cronológicas das diferentes fases de construção propostas.

Parte significativa da história destes edifícios continua porém a escapar-nos, não tendo sido sempre possível estabelecer relações cronológicas entre todas as observações realizadas, ou compor sequências de construção completas e cronologicamente contextualizadas de cada edifício. Limitações que a subsequente intervenção arqueológica a cota negativa deverá paliar através da continuidade da leitura «em profundidade» das estratificações agora observadas.

\section{FRAGMENTOS DA HISTÓRIA DOS EDIFÍCIOS}

Apesar de nos encontrarmos ainda em fase de compilação de informação relativa aos edifícios já analisados e de estar ainda por realizar a fase de escavação arqueológica que deve complementar esta intervenção global de Arqueologia preventiva, os resultados preliminares da análise do edificado demonstram já o potencial informativo da arquitectura civil quando abordada enquanto objecto histórico estratificado. Para além do acervo informativo sobre materiais e técnicas de construção, foram registadas evidências estratigráficas relativas a alterações nestas construçōes, com maior ou menor impacto sobre a sua morfologia geral ou sobre a forma como se integraram, ao longo do tempo, na malha urbana envolvente, cuja correlação resultou em propostas de faseamento construtivo e de integração histórica destes edifícios.

\subsection{Materiais e técnicas de construção: a constituição de um referencial objectivo}

Considerando o facto de trabalharmos com edifícios de arquitectura civil, frequentemente (1) menos propensos que a "grande arquitectura" à integração de elementos característicos de estilos arquitectónicos e (2) mais permeáveis à progressiva reformulação, sobreposição de soluções e, por consequência, transfiguração estilística, o conhecimento relativo ao uso de materiais e técnicas de construção, nomeadamente em termos cronológicos, constitui um elemento de base fundamental a projectos desta natureza.

No entanto, a escassez de informação contextualizada e sistematizada sobre materiais e técnicas de construção do passado no contexto português constitui hoje um condicionamento evidente à investigação.

Esta constatação exige a implementação de uma prática sistemática de amostragem contextualizada e subsequente caracterização e análise de materiais de construção em edifícios de diferentes cidades e regióes, que potenciem a definição progressiva de balizas cronológicas e áreas geográficas para o uso de diferentes materiais e técnicas de construção no contexto português.

Os trabalhos realizados na Baixinha pretendem contribuir para esse propósito, na medida em que se realizou um trabalho de documentação exaustiva de materiais e técnicas através de descrição detalhada, fotografia, desenho à escala e amostragem. Para além disso, as diferentes técnicas e materiais identificados foram rigorosamente cartografados na planta dos edifícios, a fim de documentar o seu uso em zonas específicas (cf. figura 11). Esta colecção contextualizada deverá constituir-se no núcleo original de um acervo comparativo de materiais e técnicas de construção da cidade, hoje absolutamente inexistente

Quando devidamente integrada nas propostas de faseamento dos edifícios, esta informação permitirá propor balizas cronológicas para o uso de determinados materiais e técnicas durante a história de cada edifício e produzir o referido embriāo de uma base de dados sobre estes elementos, disponível para referência em futuros projectos semelhantes na cidade e na região de Coimbra. 

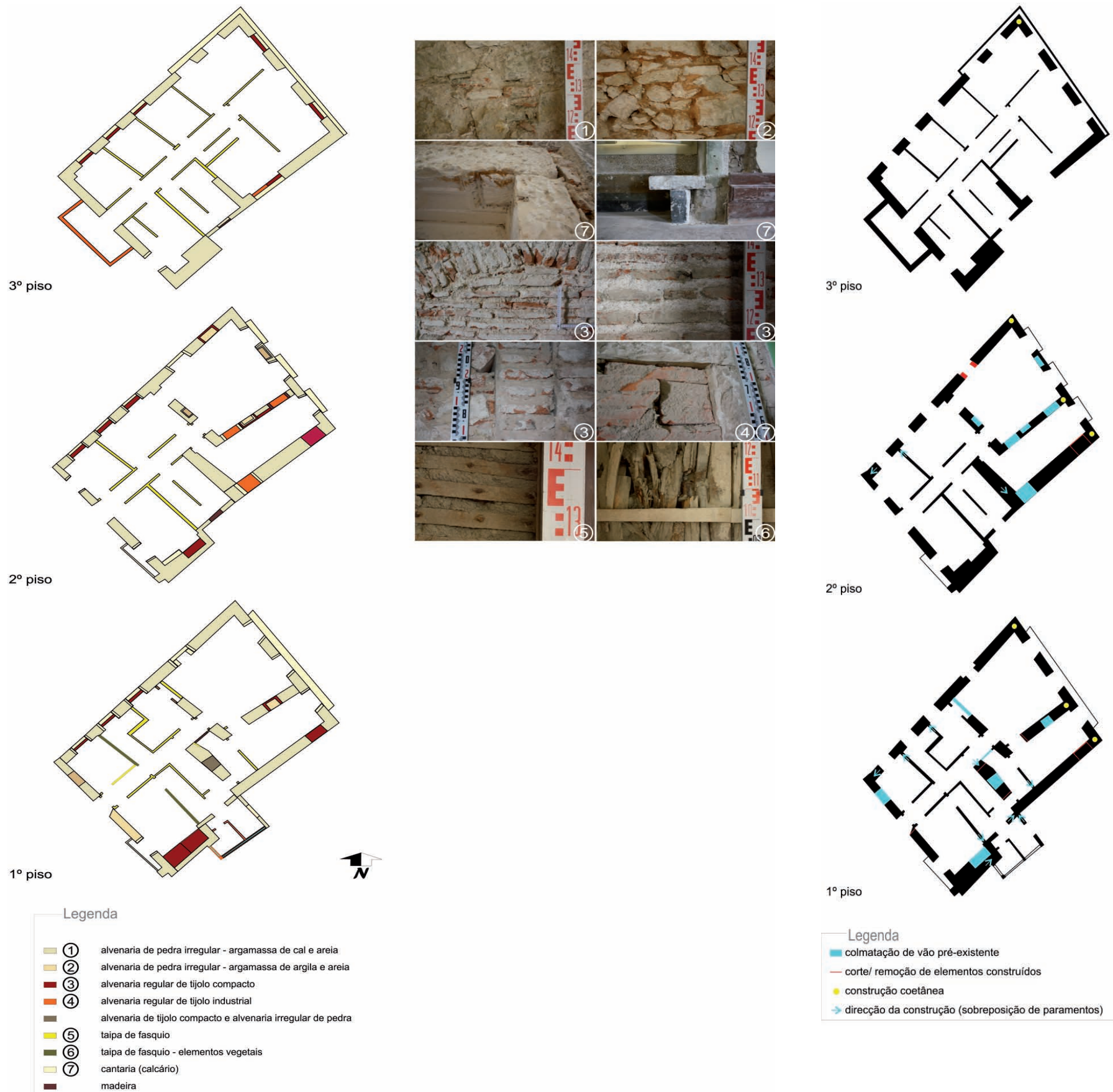

Fig. 11. Exemplos de trabalho de cartografia das observações resultantes das sondagens parietais: 1) materiais e técnicas de construção; e 2) alterações de elementos arquitectónicos e relações estratigráficas entre elementos construídos

Finalmente, porque durante a intervenção se procedeu à amostragem contextualizada de materiais de construção como uma prática sistemática, será agora possível desenhar um programa de análises com vista à caracterização destes materiais, nomeadamente da composição de tintas, argamassas e rebocos, que poderão ampliar a nossa compreensão sobre a história destes edifícios e sobre a variabilidade de opções técnicas observadas.

\subsection{Relações estratigráficas entre elementos construídos e transformações arquitectónicas}

Para além das informaçōes relativas aos materiais e técnicas de construção utilizadas, e das relações estratigráficas de sobreposição directa, registou-se um conjunto de estratificações complexas que resultam de alteraçōes substanciais dos edifícios, ainda que com impacto diferenciado na sua morfologia geral. Na maioria respeitam à supressão ou 

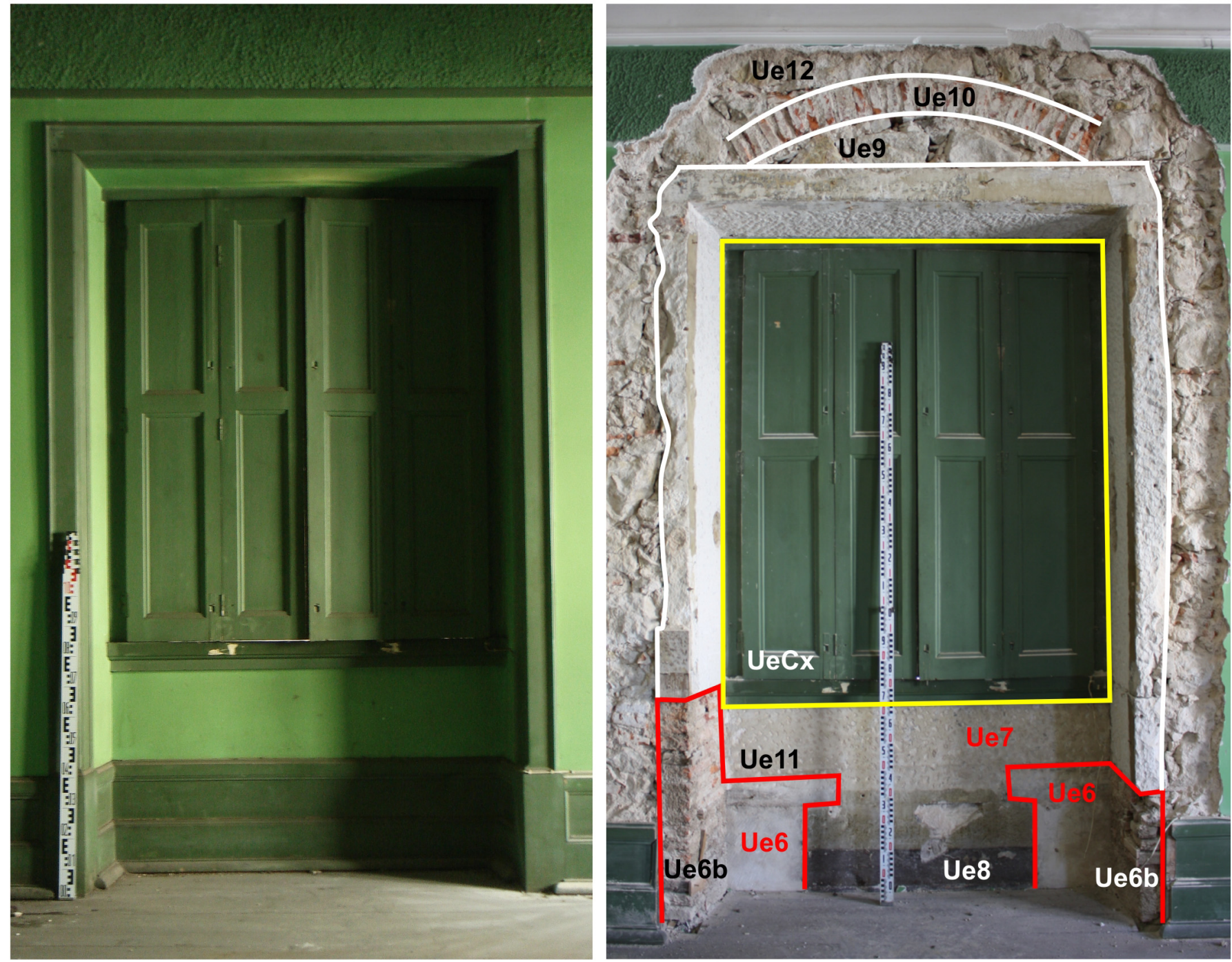

Fig. 12. Exemplo de supressão de elementos arquitectónicos: uma janela de avental com pedras «namoradeiras» integradas no vão que foram eliminadas (UE6). Toda a cantaria foi também rebocada, resultando na transformação substancial das características do vão

introdução de novos elementos arquitectónicos que, individualmente, não constituem alterações com impacto significativo nos edifícios. No entanto, a correlação de várias destas intervençôes pontuais - estabelecida com base em relaçôes estratigráficas directas, na similaridade de acções executadas ou nos materiais e técnicas de construção envolvidos - permitiu, em alguns casos, definir fases sincrónicas com alterações em diferentes locais dos edifícios, estas, eventualmente, já com impacto na sua morfologia e funcionamento.

Neste conjunto de alterações integram-se:

- alterações sem impacto significativo na composição arquitectónica dos edifícios, como a anulação ou ocultação de camadas de reboco ou de elementos arquitectónicos que não definem espaços ou per- cursos (figura 12); Embora com impacto exclusivo ao nível do detalhe, constituem evidência da existência de composiçõos arquitectónicas/ estilísticas distintas da actual, que foram anuladas em momentos concretos da história dos edifícios;

- alterações com impacto ao nível das formas de circulação e organização de espaço interior, como a abertura ou o encerramento de vãos de porta (cf. figura 9) e a supressão ou introdução de paredes (cf. figura 6), que nos remetem para momentos de reestruturação de espaços interiores;

- alterações com impacto significativo na volumetria geral do edifício e nas suas características globais, como o encerramento de determinados espaços (figura 13), ou a adição de novos volumes construídos a edifícios originais de menores dimensões. 

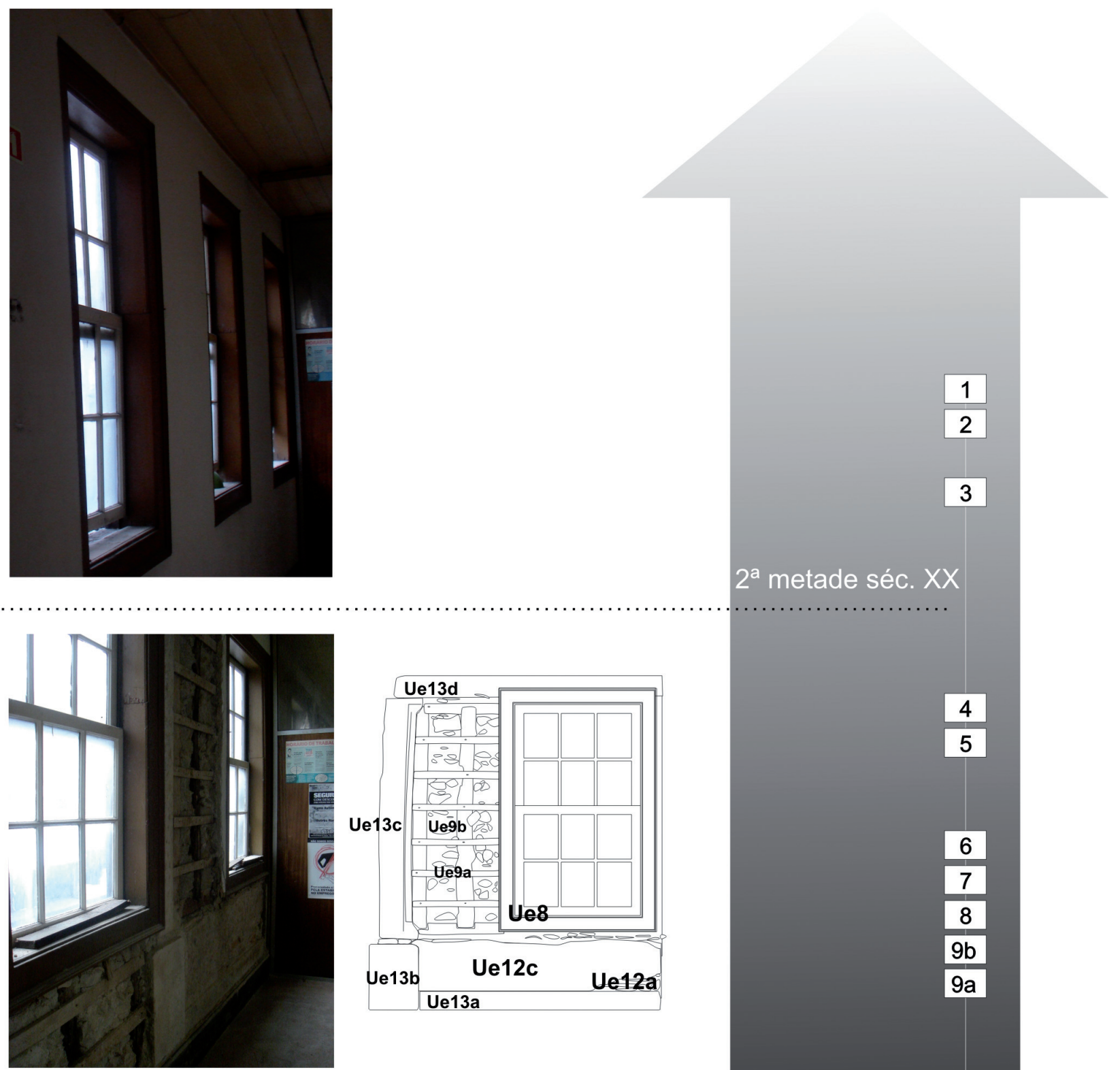

$1^{\mathrm{a}}$ metade séc. XX

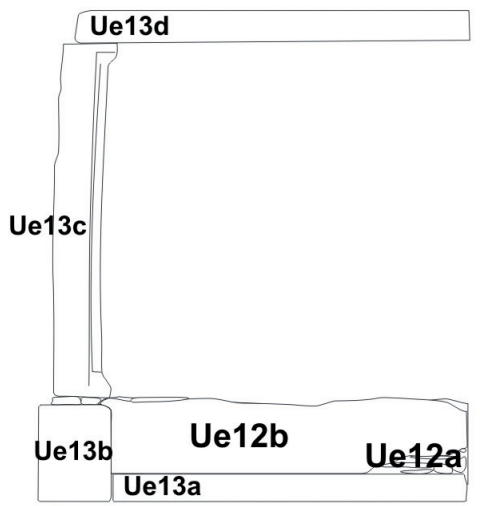




\subsection{Faseamentos construtivos, implicações no urbanismo e integração na história da cidade}

As observaçôes realizadas no decorrer dos trabalhos remetem-nos para uma evolução polifacetada e complexa dos edifícios estudados. Como seria de esperar nenhum dos cinco edifícios resulta, na sua forma actual, de um evento construtivo único. Parcial ou integralmente todos foram afectados por intervençôes de transformação, sendo resultado de acções de construção, destruição, reconstrução e remodelação, sucessivas no tempo, com impactos diferentes quer ao nível da organização e morfologia de espaços interiores, quer da sua volumetria e desenho gerais.

Para lá do faseamento construtivo dos cinco edifícios estudados, o conjunto de observações registadas tem se verificado também capaz de contribuir para a integração histórica de cada um e, consequentemente, para o objectivo mais ambicioso de reconstituição da história da área urbana envolvente. Deste modo pretende-se que as propostas de faseamento construtivo de cada edifício incluam, para além das transformações arquitectónicas e construtivas dos próprios, a sua integração a cada momento em propostas de reconstituição da história urbana da Baixinha de Coimbra.

\subsubsection{Edifício 22}

Sabemos já que o edifício 22 resulta de (pelo menos) três fases de construção distintas: a primeira de Época Medieval / inícios de Época Moderna, a segunda em momento provavelmente anterior aos séculos XVIII / XIX, e uma última reestruturação do edifício, já na $1^{\mathrm{a}}$ metade do século $\mathrm{xx}$, que lhe conferiu a sua volumetria e aspecto actuais. Todas estas realidades correspondem a momentos diferentes da história da cidade e utilizaçôes distintas deste espaço. Assim (figura 14):

- a $1^{\circ}$ fase de construção relaciona-se com a presença de um edifício de características «medievais / tardomedievais» (Trindade, 2002), de que nos chegam apenas testemunhos residuais, através das características morfólogicas de parte da fachada e de duas divisões do edifício, que estratigraficamente sabemos tratarem-se dos elementos mais antigos da construção actual. A funcionalidade exacta e modalidades de ocupação deste primeiro edifício são difíceis de estabelecer com segurança, embora alguns indícios permitam entrever uma situação de loja e sobre-loja para habitação familiar e ocupação comercial no piso térreo (Trindade, 2002);
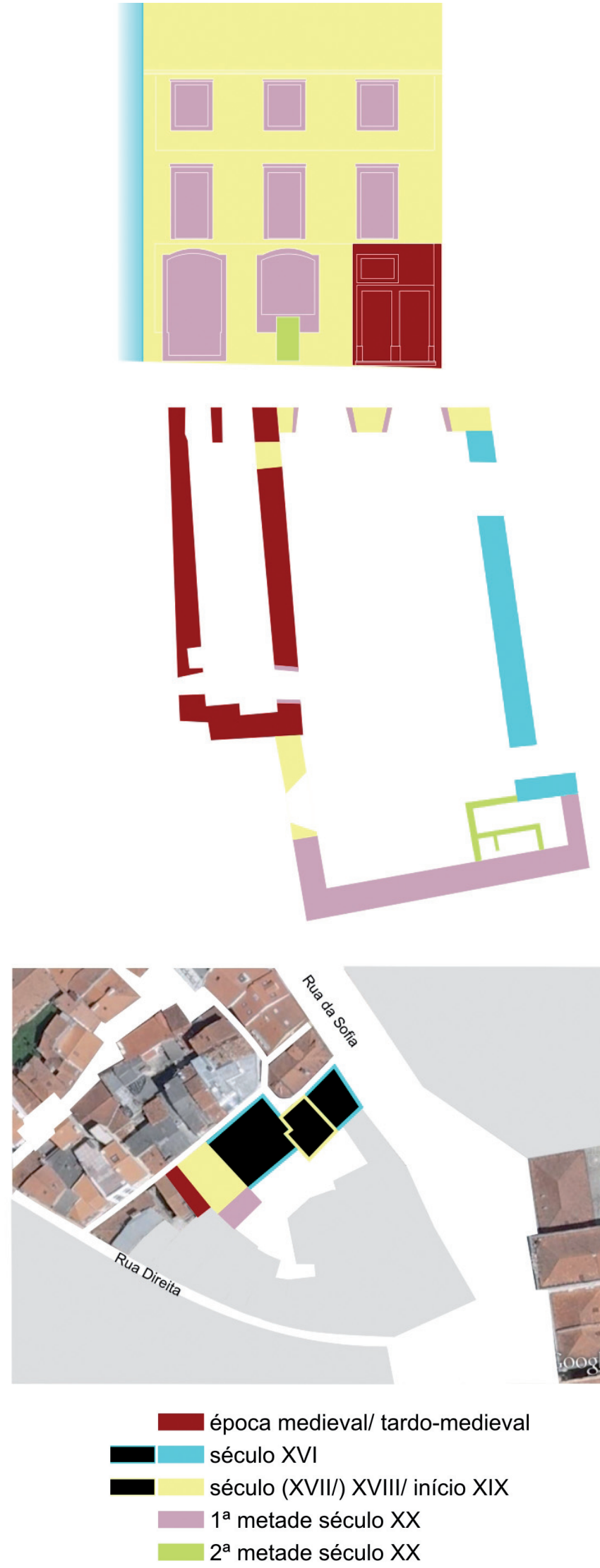

Fig. 14. Proposta de faseamento do edifício 22 e integração na malha urbana envolvente 

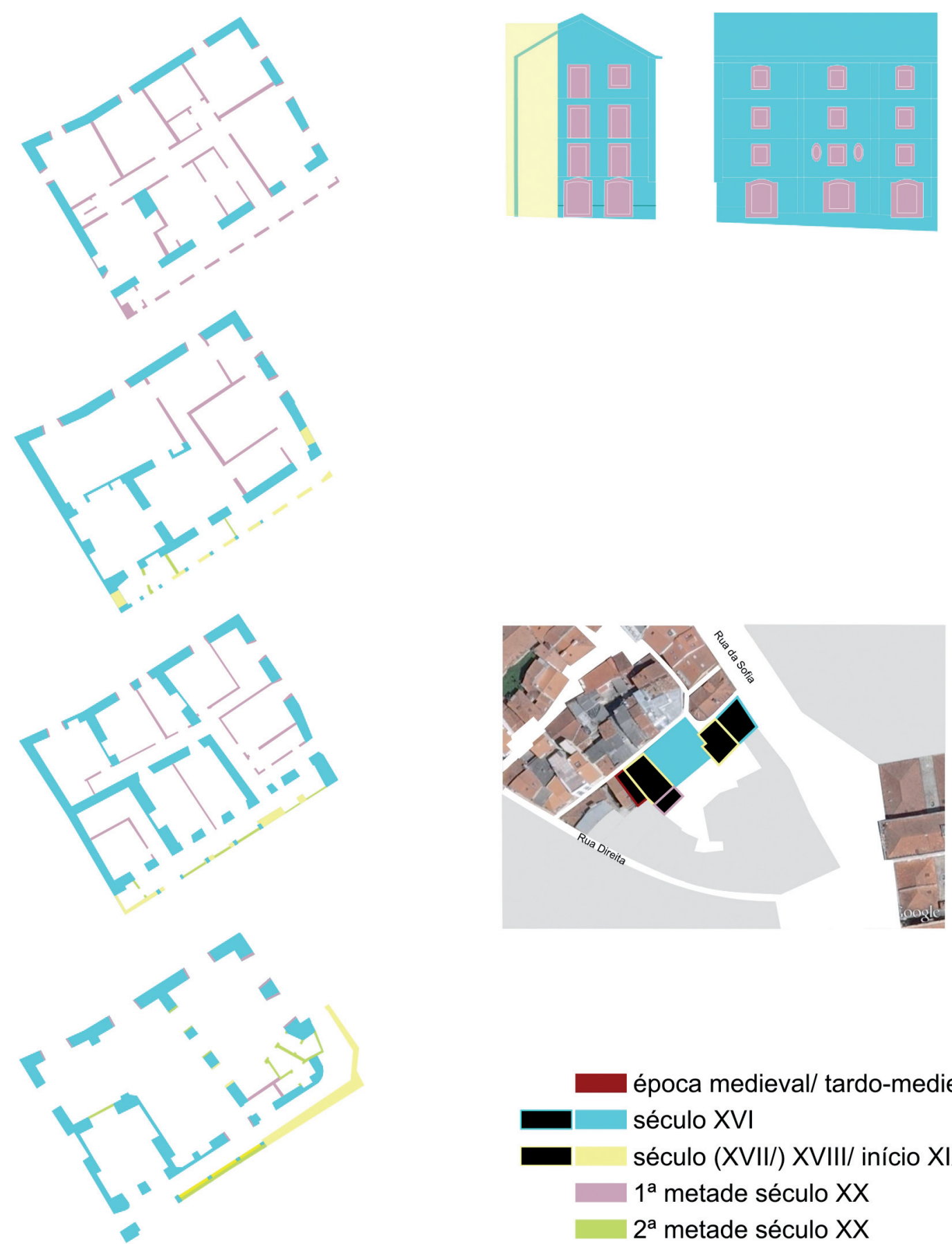

Fig. 15. Proposta de faseamento do edifício 23 e integração na malha urbana envolvente

- a $2^{\text {a }}$ fase de construção corresponde a uma ampliação da área de construção com ocupação de espaço não construído contíguo - ao qual se viravam janelas encerradas na fase anterior - e estabelecimento de relação (directa?) com o edifício lateral, cronologicamente localizada em momento anterior aos séculos XVIII / XIX, segundo a proposta de faseamento para o edifício vizinho e de acordo com a cartografia histórica dos finais do século XVIII / inícios do XIX, onde já não se regista a presença de um espaço público na área em questão;

- a última transformação registada respeita a uma fase de reestruturação recente que integra um alargamento da área de construção - hipótese suportada pelos dados cartográficos disponíveis - e à alteração integral do interior deste espaço, resultando na criação de um amplo salão no piso superior, cujas características arquitectónicas e de- 
corativas permitem integrar cronologicamente na $1^{\text {a }}$ metade do século XX. Relacionamos ainda esta fase com uma situação de homogeneização geral entre três dos cinco edifícios em análise, que para além de ganharem uma relação directa entre si, passam a integrar um conjunto de características decorativas semelhantes, devendo ter sido adquiridos pelo mesmo proprietário durante as primeiras décadas do século XX. Este espaço, terá assumido uma função estreitamente relacionada com a actividade lúdica, que manteve até à actualidade, tendo chegado a nós como adega e salão de festas de um clube recreativo.

\subsubsection{Edifício 23}

O exemplo da história construtiva do edifício 23 é substancialmente distinto: as observações realizadas permitem afirmar que os limites do edifício actual preservam a planta original, tendo-se porém verificado um conjunto significativo de transformações interiores (figura 15) - que em grande parte nos escapam no caso do edifício 22 -, nomeadamente de ampliação ou subdivisão de áreas e de anulação de elementos construídos particularmente característicos de um determinado estilo arquitectónico.

Ainda assim, estas alterações não deixaram de resultar numa transformação completa do edifício original, que integrava um conjunto de elementos de arquitectura erudita, alguns particularmente raros, relacionáveis com o tipo de construção associado à abertura da Rua da Sofia evento com impacto significativo a nível urbano, social, cultural e económico na vida da cidade (Rossa, 2001; Lobo, 2006; Alarcão, 2008) — no século XVI. Esta proposta de integração cronológica da $1^{\text {a }}$ fase de construção baseia-se, na análise da estratificação observada e das características de desenho arquitectónico, sobretudo do reconhecimento de uma estrutura de loggia (cf. figura $13 \mathrm{e}$ figura 16), composta por uma arcaria inferior e dois pisos de galeria aberta, que foi obliterada por completo em fases subsequentes da história do edifício.

A descoberta inesperada desta solução arquitectónica rara - um elemento de desenho leve de composição de fachada, que fora encerrada e transformada num descaracterizado corredor - , constitui um exemplo evidente do potencial da Arqueologia do edificado.

Com efeito, o reconhecimento deste elemento permitiu (1) definir um marco cronológico para a construção do edifício, (2) fornecer elementos estratigráficos relevantes à compreensão da evolução ulterior do edifício e (3) produzir uma proposta de reconstituição do espaço publico

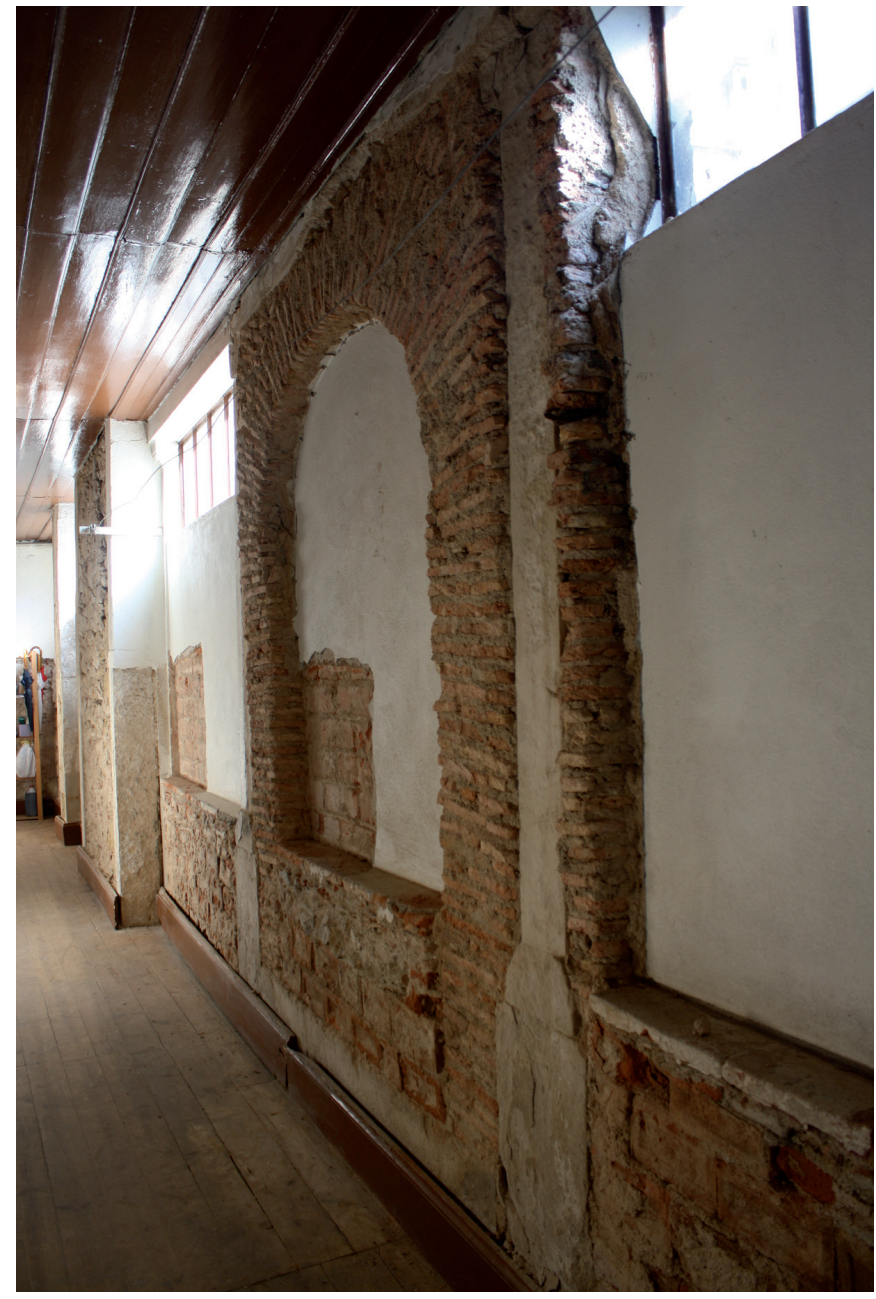

Fig. 16. Galeria do $1^{\circ}$ piso da loggia renascentista identificada no edifício 23 durante os trabalhos de sondagem parietal

envolvente à época da sua construção, substancialmente distinto do actual (figura 17): uma área mais desafogada de construção, que potenciaria o efeito cénico deste elemento, relacionada com as ruas actuais por artérias laterais ao edifício cuja existência deduzimos com base nas relações estratigráficas estabelecidas entre este edifício e os edifícios contíguos, mais recentes (figura 18).

Em termos cronológicos localizamos a $1^{\text {a }}$ (e mais significativa) fase de alteração desta construção em momento anterior aos séculos XVIII / XIX, quando a cartografia disponível nos indica que os edifícios laterais que se lhe sobrepõem (cf. figura 18) já se encontram construídos, o que terá implicado uma nova forma de circulação e de acesso ao seu interior e o encerramento (pelo menos parcial) da referida estrutura de loggia, que passa a servir como corredor interior de distribuição.

A introdução neste edifício de um conjunto de elementos arquitectónicos característicos de meados do sécu- 

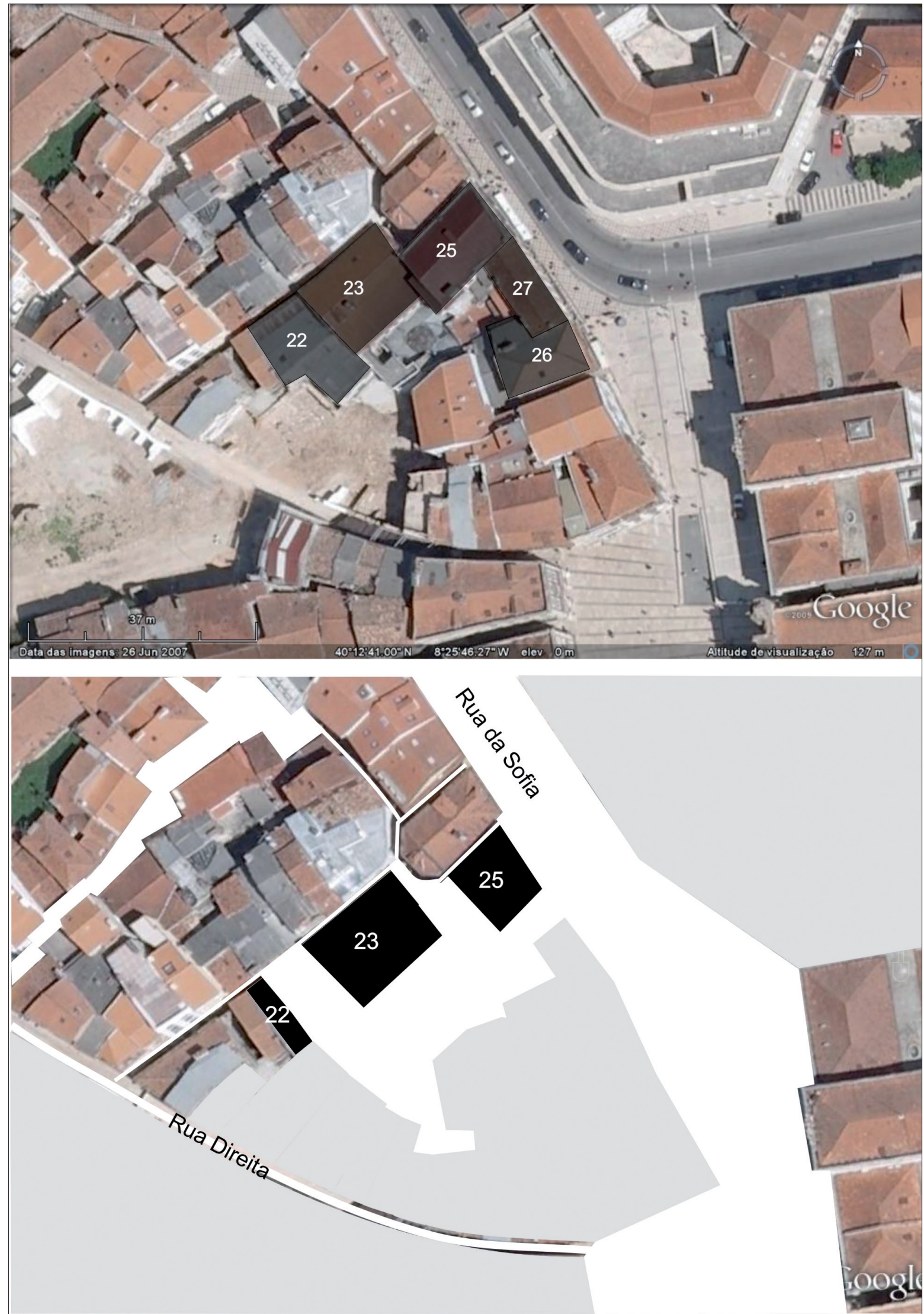

Fig. 17. Entorno actual do edifício 23 e proposta de reconstituição do mesmo espaço urbano em fase contemporânea à construção daquele edifício (século XVI/XVII) (fonte da imagem de base: Google Earth) 


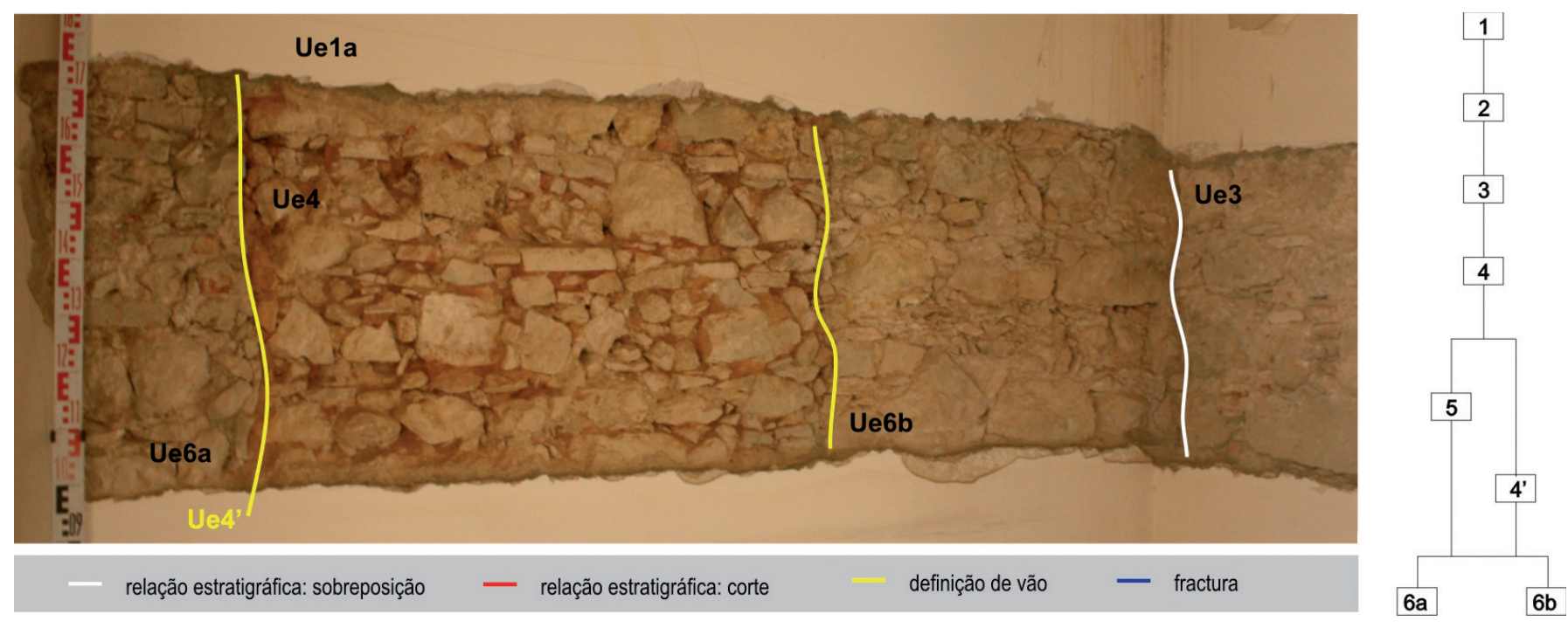

Fig. 18. Exemplo de relação estratigráfica registada entre o edifício 23 e um dos seus laterais, no caso o edifício 25, onde se pode observar: (1) o entaipamento de um vão de porta aberto na parede Ue6, limite do edifício 23 , sobre a qual se sobrepõem uma outra parede (UE3) que delimita o edifício 25 . Note-se que esta última se sobrepõem sobre uma superfície rebocada (UE5) que constitui o acabamento da parede limite do edifício 23

lo XX e a análise comparada da cartografia disponível para o início e a segunda metade do século XX, coloca em meados daquele século uma nova fase de remodelação, durante a qual se terá redefinido parte dos interiores da totalidade dos pisos e definido um novo espaço construído no último piso - um corredor sobre a estrutura de loggia então já completamente encerrada (cf. figura 15).

\section{ARTICULAÇÃO COM AS FASES SUBSEQUENTES DE ACOMPANHAMENTO E SONDAGEM ARQUEOLÓGICA}

Para além da possibilidade de investigar estes edifícios com base nos princípios do método estratigráfico, os trabalhos realizados também permitiram definir a estratégia e metodologia das fases subsequentes da intervenção arqueológica em curso, nomeadamente dos trabalhos de acompanhamento arqueológico e de sondagem arqueológica do solo. $\mathrm{O}$ conhecimento adquirido na interpretação do edificado orientará as tarefas posteriores, potenciando a procura de dados arqueológicos para validar, complementar ou infirmar as propostas de faseamento e interpretação deste espaço urbano.

No que respeita aos trabalhos subsequentes de demolição, definiram-se meios e procedimentos de desconstrução e demolição que, respeitando o faseamento proposto para cada edifício (figura 19), garantem a o acesso a mais observaçōes estratigráficas entre os elementos construídos para afinar a nossa compreensão da complexidade estratigráfica destes edifícios, em grande parte ainda oculta sob camadas de reboco. Neste sentido, definiram-se tam- bém as áreas de especial potencial informativo dos edifícios, ajustando-se, em consequência, os métodos de registo a implementar. Os princípios metodológicos estabelecidos para esta fase ulterior da intervenção visam sustentar a execução desses registos (forma e natureza dos registos gráficos, procedimentos de amostragem, etc.), para enriquecer de forma coerente a base de dados resultante da intervenção.

No que respeita à fase de sondagens arqueológicas do solo, definiram-se áreas estratégicas de intervenção por forma garantir uma continuidade das leituras de "cota positiva» que nos permita recuperar informações essenciais à aferição do rigor dos modelos interpretativos que propusemos, nomeadamente no que respeita à cronologia das diferentes fases construtivas dos edifícios. Para além disso, considerando o conhecimento actual sobre as formas de ocupação deste espaço ao longo do tempo, e a integração cronológica que fizemos dos edifícios actuais, foram também definidas áreas de intervenção com vista à determinação da presença de vestígios de ocupaçôes mais antigas, nomeadamente relacionadas com a ocupação de Época Medieval, eventualmente presentes no registo arqueológico a cota negativa sob a forma de vestígios enterrados de edifícios antigos sem representação na malha urbana actual.

Finalmente, os resultados obtidos tiveram também um impacto sobre o projecto do Metro Mondego, nomeadamente no que respeita ao projecto de arquitectura e engenharia do edifício 23, que, atempadamente, pôde ser reformulado, para incluir um trabalho de recuperação e 

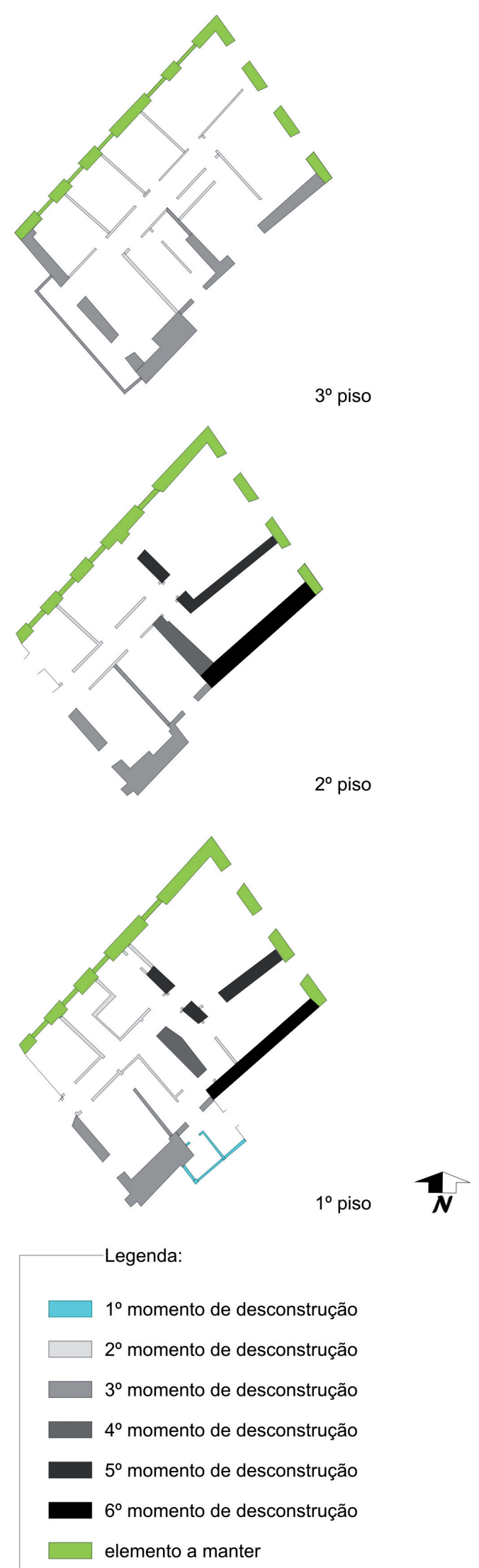

Fig. 19. Exemplo de sequência de desconstrução proposta para um dos edifícios estudados em função do seu faseamento proposto integração no novo edifício da loggia renascentista (figura 20), assim como informação relativa à sua caracterização histórica e patrimonial.

\section{ACERCA DO POTENCIAL DA ARQUEOLOGIA DO EDIFICADO EM CONTEXTO DE PREVENÇÃO E SALVAMENTO}

Em conclusão, os resultados obtidos na Baixinha de Coimbra confirmam o potencial informativo do recurso a uma abordagem global dos edifícios urbanos, fundada em métodos oriundos da Arqueologia que, quando integrados pelo contributo de outras abordagens disciplinares, permitem compreender os edifícios e o registo arqueológico que lhes subjaz enquanto documentos históricos coerentes e estratificados.

Em consequência, a disseminação do recurso a esta metodologia de trabalho no contexto específico da Arqueologia preventiva e de salvamento parece-nos essencial: (1) tanto para o desenvolvimento metodológico futuro da disciplina da Arqueologia do edificado; (2) como para a qualificação dos trabalhos de reabilitação patrimonial dos centros históricos, que não pensamos poderem compreender-se senão fundados numa compreensão diacrónica dos edifícios e dos espaços urbanos envolventes que apenas pode resultar da aplicação de uma metodologia deste género.

Nestes termos, por força do volume de dados que este esforço analítico pode produzir, pensamos que o estudo da arquitectura civil do passado constitui hoje um elemento essencial para compreender o quotidiano das sociedades pretéritas, contribuindo de forma objectiva e insubstituível para a história do urbanismo e das cidades.

A este respeito, importa insistir sobre a necessidade urgente da implementação de programas de registo e amostragem sistemática de materiais e técnicas de construção, com vista à criação de colecçôes de referência de materiais e técnicas construtivas geográfica e cronologicamente contextualizadas. Tal referencial objectivo, hoje inexistente para a Arquitectura civil das várias regiōes portuguesas, parece-nos indispensável para o progresso da nossa capacidade de interpretação da história das cidades.

Finalmente, ainda nos parece essencial - e não menos urgente! - a imposição sem reservas do princípio de "conhecer para intervir». Num contexto sócio-cultural em que se pretende promover a requalificação de zonas urbanas cuja mais-valia decorre da sua profundidade histórica, os trabalhos prévios de caracterização patrimonial e histórica não podem restringir-se à produção conheci- 


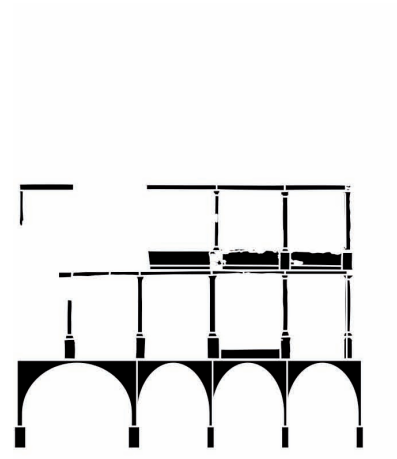

existente

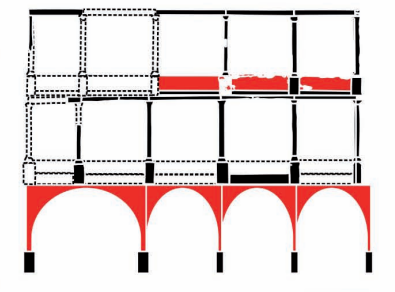

loggia

- elementos de cantaria (calcário) alvenaria de tijolo

Fig. 20. Proposta de reconstituição da loggia e de integração no alçado Sul do edifício original e estudos para integração da loggia no edifício a construir (imagem fornecida pela Metro Mondego, S.A.)

mento e registo para a posteridade. Pelo contrário, o conhecimento aprofundado da história dos edifícios e da sua envolvente urbana deve constituir-se num dos eixos fundamentais de orientação das próprias decisões estratégicas dos programas de reabilitação urbana, os quais também não devem realizar-se na ignorância de um conhecimento fundamentado da evolução diacrónica dos imóveis e espaços urbanos que visam proteger, maxime no caso de centros históricos.

A ausência desta compreensão da profundidade histórica dos edifícios e das malhas urbanas envolventes provoca frequentemente a subalternização do valor cultural e patrimonial dos edifícios enquanto documentos históricos relevantes em favor de opções de eventual carácter estético apreciável, mas desprovidas de conteúdo e peso histórico. Nestes casos falha-se por completo na protecção do valor cultural e patrimonial que justifica a própria protecção dos edifícios e dos centros urbanos históricos.

\section{Bibliografia}

Jorge de Alarcão. Coimbra: A montagem do cenário Urbano. Coimbra: Imprensa da Universidade de Coimbra. 2008.
Lília Basílio e Maria João Neves. Intervenção de Arqueologia Preventiva Trabalhos Arqueológicos na zona de intervenção da Metro Mondego na Baixinha de Coimbra, parcela 22. Relatórios Dryas, 2008. Relatório final de trabalhos arqueológicos ao IGESPAR, IP. Coimbra: Dryas Arqueologia.

Lília Basílio e Maria João Neves. Intervenção de Arqueologia Preventiva Trabalhos Arqueológicos na zona de intervenção da Metro Mondego na Baixinha de Coimbra, parcela 23. Relatórios Dryas 2008. Relatório final de trabalhos arqueológicos ao IGESPAR, IP. Coimbra: Dryas Arqueologia.

Lília Basílio e Maria João Neves. Intervenção de Arqueologia Preventiva Trabalhos Arqueológicos na zona de intervenção da Metro Mondego na Baixinha de Coimbra, adenda ao Relatório Final da parcela 23. Relatórios Dryas 2009. Relatório final de trabalhos arqueológicos ao IGESPAR, IP. Coimbra: Dryas Arqueologia.

Rui Lobo. Santa Cruz e a Rua da Sofia: arquitectura e urbanismo no século XVI. Debaixo de Telha, Série B, $n^{\circ} 6$. 2006. Coimbra: Editorial do Departamento de Arquitectura da Faculdade de Ciência e Tecnologia da Universidade de Coimbra. 2006.

J. Pinto Loureiro. Enigmas da história de Coimbra. Arquivo Coimbrão - Boletim da Biblioteca Municipal, vol. XII. Coimbra: Biblioteca Municipal de Coimbra. 1954.

Vasco G. Mantas. Notas sobre a estrutura urbana de Aeminium. Biblos, 68. Coimbra. 1992. pp. 487-513.

Maria João Neves, Lília Basílio, Susana Nunes. Intervenção de Arqueologia Preventiva - Sondagens Arqueológicas na zona de intervenção da Metro Mondego na Baixinha de Coimbra. Relatórios Dryas 2006. Relatório final de trabalhos arqueológicos ao IPA. Coimbra: Dryas Arqueologia.

Alexandre Nobre Pais, António Pacheco e João Coroado. Cerâmica de Coimbra: do século xvi ao século Xx. 2007. Coimbra: Museu Nacional Machado de Castro. 
Maria M. B. de Magalhães Ramalho. Os primeiros passos da Arqueologia da Arquitectura no âmbito do Instituto Português do Património Arquitectónico. Arqueologia de la Arquitectura, no 3. 2004.pp.145-153. Walter Rossa. Divercidade: urbanografia do espaço de Coimbra até ao estabelecimento definitivo da Universidade. Tese de doutoramento em Arquitectura (especialidade de Teoria e História da Arquitectura) apresentada à Faculdade de Ciência e Tecnologia da Universidade de Coimbra. Coimbra. 2001.
Luísa Trindade. A casa corrente em Coimbra: dos finais da Idade Média aos inícios da Época Moderna. Coimbra: Câmara Municipal de Coimbra. 2002.

Recibido: 16 de junio de 2010 Aceptado: 17 de septiembre de 2010 